\title{
PENGARUH POLA ASUH ORANG TUA TERHADAP EFIKASI DIRI SISWA KELAS V SD
}

\author{
Putu Putri Dena Laksmi ${ }^{1}$, Ni Wayan Suniasih ${ }^{2}$, Komang Ngurah Wiyasa ${ }^{3}$ \\ 1,2,3 Jurusan Pendidikan Guru Sekolah Dasar, FIP \\ Universitas Pendidikan Ganesha \\ Singaraja, Indonesia \\ e-mail: \{putridena96@gmail.com¹, niwayan.suniasih ${ }^{2}$, \\ ngrh.wiyasa@undiksha.ac.id
}

\begin{abstract}
Abstrak
Penelitian ini bertujuan untuk mengetahui pengaruh pola asuh orang tua terhadap efikasi diri siswa kelas V SD Gugus I Gusti Ngurah Rai Kecamatan Denpasar Selatan tahun ajaran 2017/2018. Jenis penelitian ini adalah penelitian ex post facto, korelasional. Populasi dari penelitian ini adalah seluruh siswa kelas V SD Negeri yang ada di Gugus I Gusti Ngurah Rai Kecamatan Denpasar Selatan tahun ajaran 2017/2018 yang berjumlah 266 orang siswa. Penentuan sampel menggunakan teknik proportional random sampling dengan taraf kesalahan 5\% sehingga diperoleh banyaknya sampel dari populasi adalah 155 orang siswa. Data pola asuh orang tua dan efikasi diri dikumpulkan menggunakan metode angket dengan skala likert dan penskoran angket menggunakan politomi. Teknik analisis data menggunakan analisis regresi linier sederhana. Sebagai uji prasyarat adalah uji normalitas sebaran data dan uji linieritas. Berdasarkan hasil analisis data menunjukkan terdapat pengaruh positif pola asuh orang tua terhadap efikasi diri siswa kelas $\mathrm{V}$ dengan kontribusi nilai $\mathrm{R}^{2}=0,035$ atau sebesar $3,5 \%$. Persamaan model regresi efikasi diri $=$ $65,89+0,34$ pola asuh orang tua. Persamaan regresi tersebut menjelaskan bahwa setiap kenaikan skor pola asuh orang tua akan menyebabkan kenaikan 0,34 peningkatan efikasi diri siswa pada konstanta 65,89. Jadi dapat disimpulkan peningkatan dalam pola asuh orang tua dapat meningkatkan efikasi siswa.
\end{abstract}

Kata-kata kunci : pola asuh orang tua, efikasi diri

\begin{abstract}
This study aims to determine the effect of parenting style pattern on self-efficacy of students of grade V SD Gusti I Gusti Ngurah Rai District South Denpasar academic year 2017/2018. This type of research is ex post facto, correlational research. The population of this study is all students of grade V elementary school in I Gusti Ngurah Rai District South Denpasar academic year 2017/2018 which amounted to 266 students. Determination of the sample using proportional random sampling technique with $5 \%$ error rate so that the number of samples obtained from the population is 155 students. Parenting style and self-efficacy were collected using questionnaire method with Likert scale and questionnaire scoring using politomy. Data analysis techniques use simple linear regression analysis. As a prerequisite test is the normality test of data distribution and linearity test. Based on the results of data analysis shows there is a positive effect of parenting style patterns of self-efficacy of students of class $\mathrm{V}$ with contribution value $\mathrm{R}^{2}=0.035$ or $3.5 \%$. Equation model of self efficacy regression $=65,89+0.34$ parenting pattern. The regression equation explains that any increase in parental parenting score will cause a 0.34 increase in self-efficacy of students at a constant of 65.89 . So it can be concluded that improvements in parenting patterns can improve student efficacy.
\end{abstract}

Keywords : parenting style, self efficacy 


\section{Pendahuluan}

Perkembangan anak sekolah dasar berada dalam periode transisi dari pertumbuhan pesat masa anak-anak ke tahap masa praremaja. Perubahan perkembangan mental maupun sosial menjadi ciri khas masa sekolah awal. Pada tahapan ini, anak dihadapkan pada berbagai perubahan yang terjadi dalam fase perkembangannya. Ada tiga aspek perkembangan pada masa anak sekolah dasar yang dikemukakan oleh Slavin (2011:101) yaitu; Perkembangan fisik, kognisi dan sosioemosi. Proses pemikiran anak juga mengalami perubahan penting periode peralihan dari tahap pemikiran praoperasi ke tahap operasi konkret. Memasuki tahap operasi konkret, anak-anak usia sekolah dasar dengan pesat mengembangkan kemampuan daya ingat dan kognisi, termasuk kemampuan meta-kognisi, yaitu kemampuan memikirkan pemikiran mereka sendiri dan mempelajari cara belajar. Siswa yang merasa yakin dengan kemampuannya menggunakan perilaku metakognisi dan motivasi diri mungkin akan mempunyai keyakinan yang tinggi. Keyakinan sebagai upaya diri anak itu sendiri menentukan keberhasilan atau kegagalannya. Namun, tidak semua anak mengalami peralihan pada usia yang sama, dan tidak satu pun anak berubah dari tahap satu ke tahap berikut dengan cepat. Hal ini disebabkan oleh faktor-faktor yang mempengaruhi perkembangan anak itu sendiri yang meliputi hereditas (keturunan/pembawaan) dan lingkungan perkembangannya.

Masalah akan muncul ketika anak tidak siap menghadapi kenyataan akibat dari ketidakyakinan akan diri dan kemampuan mereka sendiri, sehingga membuat mereka menjadi takut untuk pergi ke sekolah dan menutup diri dengan lingkungannya. Hal ini juga didukung oleh informasi yang didapat dari guru wali kelas V SD di Gugus I Gusti Ngurah Rai, didapatkan data bahwa sebagian besar anak yang memiliki masalah dalam belajar, seperti malu dalam mengutarakan pendapat, memiliki ketakutan untuk pergi ke sekolah, semangat belajar yang masih rendah, ragu-ragu dalam menjawab pertanyaan dari guru sehingga menyebabkan anak memiliki kecemasan yang berlebihan, hal ini disebabkan akibat dari ketidakyakinan terhadap apa yang ia kerjakan yang dalam hal ini dipengaruhi oleh lingkungan itu sendiri yang menyebabkan dalam fase perkembangan anak akan terganggu. Dalam perkembangan anak ada tugas perkembangan yang harus dapat dilalui anak seperti mereka di tuntut untuk dapat bergaul dengan teman-teman sebaya, mengembangkan keterampilan dasar, dan belajar untuk mandiri membuat rencana yang bebas dari pengaruh orang tua dan orang lain. Maka dari pada itu, anak usia sekolah dasar perlu mengembangkan keyakinan dirinya sendiri bahwa mereka mampu melewati dan menjalankan perubahan-perubahan yang terjadi dalam dirinya. Keyakinan tersebut dikatakan sebagai efikasi diri. Sejalan dengan hal tersebut Albert Bandura (1997) berpendapat, efikasi diri mampu membuat seorang anak menentukan pilihan, seberapa besar usaha mereka untuk maju, kegigihan dan ketekunan yang mereka tunjukkan untuk menghadapi suatu permasalahan atau perubahan-perubahan yang terjadi di sekitarnya. Setiap orang percaya bahwa dirinya memiliki potensi untuk mengubah hal-hal yang ada di sekitarnya dan bertindak aktif dibandingkan oleh orang yang memiliki efikasi diri yang rendah. Lebih lanjut di jelaskan bahwa, pembentukan efikasi diri pada seseorang tidak terlepas dari peran lingkungan sekitar.

Awal pertumbuhan dari efikasi diri berkembang melalui peran orang tua, kemudian dipengaruhi oleh saudara kandung, teman sebaya, dan orang dewasa lainnya. Peran orang tua sangatlah penting bagi anak, karena anak akan menjadikan orangtua sebagai model bagi perilakunya. Ini berarti anak mengikuti perilaku orangtuanya, bahkan lebih dari itu anak juga akan mengikuti pandangan, pola pikir dan nilai-nilai yang dianut oleh orang tua. Jelaslah peran keluarga menjadi yang utama bagi perkembangan perilaku anak. Dengan demikian, keluarga merupakan lembaga sosialisasi yang pertama di dapat oleh anak dan menjadi hal yang utama dalam proses perkembangan anak.

Orang tua memiliki cara yang berbeda-beda dalam mendidik anaknya, salah satunya dengan menerapkan pola asuh. "Pola asuh orang tua merupakan segala bentuk dan proses 
interaksi yang terjadi antara orangtua dan anak" (Mulyadi, 2016:183). Apabila pola asuh orang tua dan interaksi dengan anggota keluarga yang lain baik, maka menjadi salah satu faktor pendukung pembentukan efikasi diri yang positif pada anak. Anak menjadi akan lebih mandiri dalam menyelesaikan permasalahan yang dihadapi. Maka dari pada itu, bahwa pola asuh orang tua menjadi salah satu faktor penentu pembentukan efikasi siswa.

Adapun tujuan penelitian ini yaitu: untuk mengetahui pengaruh pola asuh orang tua terhadap efikasi diri siswa kelas V SD Gugus I Gusti Ngurah Rai Tahun Ajaran 2017/2018.

Setiap individu memiliki keyakinan yang berbeda-beda. Keyakinan ini perlu dikembangkan agar individu tersebut dapat memiliki pendirian yang kuat untuk menghadapi tantangan yang dilalui oleh individu tersebut. Sejalan dengan hal tersebut seorang pakar dalam bidang psikologi perkembangan yakni Albert Bandura pada tahun 1986 mengemukakan teori self efficacy atau dalam hal ini dibahas sebagai efikasi diri.

Efikasi diri didefinisikan sebagai orang-orang tentang kemampuan untuk menghasilkan tingkat kinerja yang ditentukan melalui suatu peristiwa yang dapat mempengaruhi kehidupan. Keyakinan dalam diri menentukan bagaimana orang merasa, berpikir, memotivasi diri dan berperilaku. Keyakinan semacam itu menghasilkan efek beragam ini melalui empat proses utama. Empat proses utama tersebut meliputi: kognitif, motivasi, afektif dan seleksi. Lebih lanjut self efficacy akan dibahas sebagai efikasi diri. Bandura menyatakan bahwa efikasi merupakan keyakinan yang dipegang seseorang tentang kemampuannya dan juga hasil yang ia peroleh dari kerja kerasnya mempengaruhi cara berperilaku (Bandura, 1997). Seseorang bertingkahlaku dalam situasi tertentu tergantung kepada resiprokal antara lingkungan dengan kondisi kognitif, khususnya faktor kognitif yang berhubungan dengan keyakinan bahwa mampu atau tidak mampu melakukan tindakan yang memuaskan. Lebih lanjut Bandura menjelaskan dalam teori sosial kognitif, bahwa efikasi diri dapat membantu seseorang dalam menentukan pilihan, bagaimana usaha untuk maju, kegigihan dan ketekunan yang ditunjukan dalam menghadapi kesulitan, dan derajat kecemasan atau ketenangan yang dialami saat mempertahankan tugas-tugas yang mencangkupi kehidupan. Sehingga efikasi diri dapat mempengaruhi keyakinan individu dapat menguasai situasi dan memperoleh hasil yang positif atas yang dikerjakan oleh seseorang.

Alwisol (2014) berpendapat bahwa efikasi adalah penilaian diri, apakah dapat melakukan tindakan yang baik atau buruk, tepat atau salah, bisa atau tidak bisa mengerjakan sesuai dengan yang dipersyaratkan. Efikasi diri dapat menggambarkan penilaian kemampuan diri seseorang.

Sehingga berdasarkan definisi di atas, dapat disimpulkan bahwa efikasi diri merupakan keyakinan atau kepercayaan individu terhadap kemampuan yang dimilikinya dalam melaksanakan dan menyelesaikan tugas-tugas yang dihadapi, sehingga mampu mengatasi rintangan dan mencapai tujuan yang diharapkannya.

Bandura (1997) menyatakan bahwa efikasi diri berkembang secara teratur. Dari usia dini mulai mengembangkan efikasi diri sebagai usaha untuk melatih kemampuan menghadapi lingkungan fisik maupun sosial. Anak mulai mengerti dan belajar mengenai kemampuan dirinya, kecakapan fisik, kemampuan sosial, dan kecakapan berbahasa yang hampir secara konstan digunakan dan ditunjukan pada lingkungan. Awal dari pertumbuhan efikasi diri dipusatkan pada orang tua kemudian dipengaruhi oleh saudara kandung, teman sebaya, dan orang dewasa lainnya. Efikasi pada masa dewasa meliputi penyesuaian pada masalah perkawinan dan peningkatan karir. Hingga sampai pada masa lanjut usia, namun pada usia ini sulit terbentuk sebab pada masa ini terjadi penurunan mental dan fisik, pensiun kerja, dan penarikan diri dari lingkungan sosial. Secara klasifikasi efikasi dibagi menjadi dua bentuk yaitu efikasi diri yang tinggi dan efikasi diri yang rendah (Anwar,2009). Individu yang memiliki efikasi diri yang tinggi memiliki semangat dan serius untuk mengerjakan tugas, sekalipun tugas-tugas tersebut merupakan tugas yang sulit. Individu tersebut tidak memandang tugas sebagai suatu ancaman, sehingga tidak harus menghindari tugas tersebut. Selain itu bagi individu yang memiliki efikasi diri yang tinggi menganggap tugas sebagai bagian untuk mengembangkan minat atau ketertarikan yang mendalam terhadap 
suatu aktivitas, mengembangkan tujuan, dan berkomitmen dalam mencapai tujuan tersebut. Individu yang memiliki efikasi yang tinggi juga akan meningkatkan usaha dalam mencegah kegagalan yang mungkin timbul. Jika individu tersebut gagal dalam melaksanakan sesuatu, biasanya cepat mendapatkan kembali efikasi diri setelah mengalami kegagalan tersebut. Berbanding terbalik dengan individu yang memiliki efikasi diri yang rendah cenderung akan menjauhi tugas-tugas yang sulit karena tugas tersebut dipandang sebagai ancaman baginya. Individu tersebut akan memiliki aspirasi yang rendah serta komitmen yang rendah dalam mencapai tujuan yang dipilih atau ditetapkan. Ketika menghadapai tugas-tugas yang sulit, anak akan sibuk memikirkan kekurangan-kekurangan dirinya, gangguan-gangguan yang dihadapi, dan semua hasil yang dapat merugikan. Individu yang memiliki efikasi yang rendah tidak berpikir tentang bagaimana cara yang baik dalam menghadapi tugas-tugas yang sulit. Saat menghadapi tugas yang sulit, anak akan mengurangi usaha-usaha dan cepat menyerah. Anak juga lamban dalam membenahi ataupun mendapatkan kembali efikasi dirinya ketika menghadapi kegagalan.

Efikasi dapat berkembang melalui beberapa sumber. Sumber efikasi diri tersebut dapat menyebabkan peningkatan maupun penurunan efikasi diri itu sendiri. Empat sumber utama efikasi yakni: pengalaman performansi, pengalaman vikarius, persuasi sosial, dan keadaan fisiologis emosi. Keempat sumber ekspektasi efikasi di atas dapat diperoleh, diubah, ditingkatkan atau diturunkan oleh individu sesuai dengan keadaan diri orang tersebut. Pengubahan efikasi diri banyak dipakai untuk memperbaiki kesulitan dan adaptasi tingkah laku orang yang mengalami berbagai masalah behavioral.

Dalam efikasi diri terdapat beberapa dimensi yang dapat mengklasifikasikan tingkatan efikasi diri seseorang. Hal ini berkenaan dalam menentukan seberapa besar efikasi diri individu tersebut dalam menghadapi suatu permasalahan. Menurut Bandura tahun (1977:194) menyatakan bahwa; analisis ekspektasi efikasi diri memerlukan penilaian rinci tentang magnitude, generality, and strength dari ekspektasi efikasi yang sepadan dengan ketepatan proses perilaku yang diukur. Baik ekspektasi dan kinerja efikasi harus dinilai dengan detail agar proses perubahan dapat mengklarifikasi efek timbal balik satu sama lain. Ekspektasi penguasaan mempengaruhi kinerja dan pada gilirannya diubah oleh orang itu sendiri. Jadi efikasi diri dibedakan atas tiga dimensi yaitu: Level/magnitude, generallity dan strength. Masing-masing dimensi mempunyai implikasi penting dalam performansi (Bandura, 1997).

1) Level/magnitude, yaitu penilaian kemampuan individu pada tugas yang sedang dihadapinya. Dimensi ini mengacu pada tingkat kesulitan dalam menghadapi suatu masalah yang dipersepsikan berbeda dari setiap individu. Ada yang menganggap masalah itu sulit untuk dilakukan dan ada pula yang menganggap mudah untuk dilakukan. Apabila individu merasa sedikit rintangan yang dihadapi maka masalah tersebut mudah ditangani. Dengan demikian dimensi ini merupakan masalah yang berkaitan dengan derajat kesulitan tugas individu. Komponen ini berimplikasi pada pemilihan perilaku yang akan dicoba individu berdasarkan harapan atau ekspektasi efikasi pada tingkat kesulitan tugas tersebut. Individu akan berupaya melakukan tugas tertentu yang diharapkan dapat dilaksanakannya dan individu akan menghindari situasi dan perilaku yang dipersepsikan diluar batas kemampuannya.

2) Generality, yaitu dimensi yang mengacu pada penilaian efikasi individu berdasarkan aktifitas keseluruhan tugas yang pernah dijalaninya. Generality berkaitan dengan tingkah laku dimana individu merasa yakin terhadap kemampuannya, tergantung kepada pemahaman kemampuan dirinya yang terbatas pada suatu aktifitas dan situasi yang lebih luas dan bervariasi. Jadi, generality dapat dikatakan sebagai keyakinan siswa terhadap kemampuan yang dimiliki dalam menggeneralisasikan tugas-tugasnya, berdasarkan dengan pengalamannya.

3) Strength, mengacu pada ketahanan dan keuletan individu dalam menyelesaikan masalah. Individu yang memiliki keyakinan yang kuat terhadap kemampuannya untuk menyelesaikan masalah akan terus bertahan dalam usahanya meskipun banyak kesulitan dan tantangan. Dengan efikasi diri, kekuatan untuk usaha yang lebih besar mampu didapat. 
Semakin kuat perasaan efikasi diri dan semakin besar ketekunan, maka semakin tinggi kemungkinan kegiatan yang dipilih dan dilakukan dengan berhasil. Pengharapan yang kuat dan mantap pada individu akan mencapai tujuan, walaupun mungkin belum memiliki pengalaman yang menunjang. Sebaliknya, pengharapan yang lemah dan ragu-ragu terhadap kemampuan diri, akan mudah digoyahkan oleh pengalaman yang tidak menunjang. Jadi, yang dimaksud strength adalah taraf keyakinan siswa terhadap kemampuan yang dimilikinya, dalam mengatasi masalah yang muncul dari penyelesaian tugas-tugasnya.

Menurut Alwisol (2014:290), sumber pengontrol tingkah laku adalah resiprokal antara lingkungan, tingkah laku dan pribadi. Efikasi diri merupakan variabel pribadi yang penting, yang digabung dengan tujuan-tujuan spesifik dan pemahaman mengenai prestasi, akan menjadi penentu tingkah laku mendatang yang penting. Setiap individu mempunyai efikasi diri yang berbeda-beda pada situasi yang berbeda, tergantung kepada: (1) Kemampuan yang dituntut oleh situasi yang berbeda itu. (2) Kehadiran orang lain, khususnya saingan dalam situasi itu. (3) Keadaan fisiologis dan emosional, kelelahan, kecemasan, apatis, murung.

Efikasi yang tinggi atau rendah, dikombinasikan dengan lingkungan yang responsif atau tidak responsif, akan menghasilkan kemungkinan prediksi tingkah laku.

Pola asuh merupakan pola sikap atau cara orang tua mendidik, mempengaruhi dan memberikan perlakuan terhadap anak dalam mencapai suatu tujuan yang ditujukan oleh sikap perubahan tingkah laku pada anak. Penelitian kontemporer pada gaya pola asuh berasal dari penelitian terkenal Diana Baumrind tahun 1966, ia menyebutkan bahwa, menjadi orang tua adalah aktivitas kompleks yang mencakup banyak perilaku khusus yang bekerja secara individual dan bersama-sama untuk mempengaruhi hasil anak. Keharmonisan keluarga sangat membantu individu melewati masa-masa sulit ketika menjalani proses belajar. Orang tua memiliki cara yang berbeda-beda dalam mendidik anaknya, salah satunya dengan menggunakan penerapan pola asuh yang berbeda.

Mulyadi dkk (2016:185) menyebutkan bahwa, pola asuh merupakan segala bentuk dan proses interaksi yang terjadi antara orang tua dan anak yang merupakan pola pengasuhan tertentu dalam keluarga yang akan memberi pengaruh terhadap perkembangan kepribadian anak. Pola asuh orang tua dan interaksi yang baik dengan anggota keluarga merupakan salah satu faktor pendukung untuk pembentukan efikasi diri yang positif terhadap anak. Pengajaran dan pengasuhan dapat membentuk kemandirian yang baik pada anak.

Yusuf (2017:48) mengemukakan bahwa pola asuh adalah sikap atau cara orang tua mendidik dan mempengaruhi anak dalam mencapai suatu tujuan yang ditujukan oleh sikap perubahan tingkah laku pada anak. Cara pendidikan dalam keluarga yang berjalan dengan baik akan menumbuhkan perkembangan kepribadian anak menjadi pribadi yang kuat dan memiliki sikap positif jasmani dan rohani serta intelektual yang berkembang secara optimal.

Berdasarkan penjelasan di atas, dapat disimpulkan bahwa pola asuh merupakan segala bentuk proses interaksi meliputi sikap atau cara orang tua mendidik dan mempengaruhi anak untuk memberi pengaruh yang positif terhadap perkembangan kepribadian anak yang kuat baik dari jasmani, rohani dan intelektual yang diharapkan dapat berkembang secara optimal.

Konsep gaya pengasuhan Diana Baumrind, membangun gaya pengasuhan digunakan untuk menangkap variasi normal dalam upaya kontrol orang tua dan mensosialisasikan anak-anak. Diana menyebutkan (1991), ketika orang tua sangat menuntut namun, disisi lain memberikan kebebasan kepada anak untuk mengatur dirinya sendiri agar sesuai dengan tingkat perkembangan anak. Tuntutan tersebut mengacu pada kontrol yang dibuat orang tua pada anak-anak untuk diintegrasikan ke dalam seluruh anggota keluarga yang meliputi; tuntutan kedewasaan, pengawasan, upaya disiplin dan kesediaan untuk menghadapi anak yang tidak taat. Responsivitas mengacu pada sejauh mana orang tua dengan sengaja menumbuhkan individualitas, pengaturan diri, dan 
penegasan diri dengan menyesuaikan diri, mendukung, dan menyetujui kebutuhan dan tuntutan khusus anak-anak sehingga terdapat dua dimensi yang dianggap signifikan dalam pola asuh. Dua dimensi tersebut adalah kontrol dan responsivitas. Dimensi kontrol meliputi tuntutan yang diberikan orangtua pada anak agar anak menjadi individu yang dewasa dan bertanggungjawab serta memberlakukan aturan dan batasan yang sudah ditetapkan. Dimensi responsivitas meliputi dukungan kehangatan dan kasih sayang yang ditunjukkan orangtua kepada anak.

Keterkaitan antara dimensi kontrol dan responsibilitas dapat membentuk beberapa jenis pola asuh. Pola asuh tersebut dibagi menjadi tiga sesuai dengan hasil penelitian dari Baumrind yang dilakukan melalui metode observasi dan wawancara terhadap siswa taman kanak-kanak yang dilakukannya, baik di rumah maupun di sekolah dengan tujuan untuk mengetahui gaya perlakuan orang tua (parenting style) dan kontribusinya terhadap kompetensi sosial, emosional dan intelektual siswa. Baumrind melaporkan tiga gaya perlakuan pengasuhan yakni; Authoritarian, Permissive, Authoritative.

Jika orang tua memberikan responsivitas dan kontrol yang seimbang dikategorikan sebagai pola asuh authoritative. Orang tua yang memberikan kontrol tanpa disertai dengan responsivitas disebut sebagai pola asuh authoritarian. Sebaliknya, jika orang tua memberikan responsivitas tanpa adanya kontrol, maka dapat disebut sebagai pola asuh permissive. Berikut merupakan penjelasan rinci mengenai ketiga pola asuh tersebut.

a) Pola asuh Authoritative

Pola asuh authoritative ditunjukan oleh tingginya tingkat kontrol dan tuntutan kedewasaan, dalam konteks pengasuhan. Pendisiplinan melibatkan penggunaan logika dan kekuasaan, tetapi tidak sampai melewati batas otonomi anak. Pola asuh authoritative memiliki keseimbangan antara dimensi kontrol dan responsivitas. Orang tua menerapkan sistem musyawarah dalam pengembalian keputusan dan mendorong komunikasi verbal timbal balik. Selain itu, orang tua juga memberikan afeksi positif (kasih sayang, kehangatan dan penerimaan) pada anak. Pola asuh authoritative menghasilkan remaja dengan kemampuan sosial, self-esteem dan performansi sekolah yang baik. Anak yang baik juga memiliki kematangan emosi yang stabil dan jarang terlibat dengan perilaku bermasalah serta memiliki tingkat depresi yang rendah. Hal tersebut dikarenakan orang tua mampu memberikan pemantauan, pendisiplinan yang efektif serta memberikan dukungandukungan yang diperlukan oleh anak (Santrock, 2007).

b) Pola asuh Authoritarian

Pola asuh authoritarian didefinisikan dengan tingginya tingkat tuntutan dan kontrol pada anak disertai dengan rendahnya tingkat responsivitas. Orangtua dengan pola asuh authoritarian mendorong anak mengikuti seluruh arahan orang tua. Orang tua memberlakukan hukuman terhadap perilaku anak yang menyimpang dari pengasuhan orang tua. Dalam pola asuh authoritarian, dimensi kontrol lebih menonjol dibandingkan dengan dimensi responsivitas. Orang tua menetapkan batsan yang tegas dan tidak memberi peluang yang cukup untuk anak dapat menyampaikan pendapatnya. Orang tua lebih mengambil jarak dan tidak hangat. Anak yang diasuh oleh orangtua authoritarian memiliki performansi sekolah yang baik dan jarang memiliki perilaku bermasalah. Tetapi, anak yang menerima pola asuh ini cenderung mudah depresi serta memiliki kemampuan sosial dan self-esteem yang rendah. Pemantauan dan pendisiplinan dengan cara menghukum membuat anak cenderung berusaha berperilaku baik dan memenuhi tuntutan orang tua agar terhindar dari Hukuman. Akan tetapi, kurangnya dukungan dan kehangatan pada anak akan berdampak pada kurangnya kemampuan sosial anak.

c) Pola asuh Permissive

Pola asuh permissive ditandai dengan tingginya tingkat responsivitas akan tetapi orang tua kurang memberikan tuntutan dan kontrol pada anak. Orangtua permissive sangat terlibat dengan anak namun tidak terlalu menuntut atau mengkontrol. Orang tua membiarkan anak melakukan apa saja yang diinginkan. Orang tua hanya membuat sedikit permintaan dan membiarkan anak memonitor aktivitas anak sendiri. Orang tua cenderung hangat, tidak mengkontrol, dan tidak menuntut. 
Orang tua dengan pola asuh permissive terbuka secara afeksi namun tidak memberikan batasan pada anak. Akibatnya anak kurang mampu mengendalikan tingkah laku dan melakukan apapun yang ingin dilakukan. Anak juga mengalami kesulitan untuk menjalin relasi dengan lingkungan sosialnya. Dampak lain yang diterima anak adalah ketidakmampuan anak untuk berempati dengan orang lain.

Efikasi diri memiliki kaitan yang erat dengan pola pengasuhan orang tua, dimana awal pertumbuhan efikasi diri dipusatkan pada orang tua yang kemudian dipengaruhi oleh saudara kandung, teman sebaya dan orang dewasa lainnya yang berada di sekitar anak itu sendiri. Hal tersebut juga berkaitan erat dengan sumber efikasi yang menyebutkan bahwa anak akan cenderung mengikuti model sosial serta dukungan sosial dari orang terdekat dan paling lekat dengan kehidupan anak yakni orang tua. Orang tua akan sebagai figur pertama yang akan diamati oleh anak. Apabila sosok figur yang diamati memiliki keberhasilan dan mendukung anak, maka ia akan cenderung memiliki efikasi yang tinggi, sebaliknya efikasi diri akan menurun jika figur yang diamati oleh anak memiliki kegagalan dan kurang mendukung anak. Jelas maka efikasi diri dapat ditingkatkan dan diturunkan oleh dukungan dan peran orang tua. Lebih lanjut ada beberapa faktor yang mempengaruhi efikasi anak itu sendiri yakni dari budaya yang dianut oleh orang terdekat anak yang dapat memberikan penilaian efikasi anak apakah anak tersebut tinggi atau rendah. Kemudian berdasarkan gender yang mempengaruhi efikasi diri. Anak perempuan cenderung memiliki efikasi diri yang tinggi dibandingkan anak laki-laki karena anak perempuan dapat mengelola tugastugas yang diberikan dibandingkan anak laki-laki. Selanjutnya bedasarkan sifat tugas yang dihadapi, kecendrungan insentif eksternal, Status atau peran anak tersebut dalam lingkungannya, dan informasi tentang kemampuan dirinya baik positif maupun negatif samasama memiliki kecendrungan untuk dapat meningkatkan atau dapat menurunkan efikasi diri anak. Maka dari pada itu, efikasi diri memiliki kaitan yang erat dengan orang tua terutama terletak bagaimana anak tersebut di berikan perlakuan maupun pengasuhan. Pemberian perlakuan dan pengasuhan yang tepat akan meningkatkan efikasi anak tersebut.

\section{Metode}

Penelitian ini termasuk jenis penelitian ex post facto dengan studi korelasional karena dalam penelitian ini hanya mengungkapkan gejala yang terjadi seperti apa adanya serta mengungkapkan faktor-faktor yang berpengaruh dari variabel bebas terhadap variabel terikat. Dalam penelitian ini dibahas mengenai seberapa besar pengaruh pola asuh orang tua terhadap efikasi diri. Pola asuh orang tua akan mempengaruhi keyakinan dan kepercayaan diri anak dalam hal ini efikasi dalam diri anak sehingga, anak dapat mandiri dan mampu mengembangkan kemampuannya sendiri.

Penelitian ini dilakukan bulan februari 2018 sampai dengan bulan mei 2018. Lokasi penelitian yaitu SD Negeri Gugus I Gusti Ngurah Rai Kecamatan Denpasar Selatan Tahun Ajaran 2017/2018.

Populasi dalam penelitian ini adalah seluruh siswa kelas V SD Gugus I Gusti Ngurah Rai Kecamatan Denpasar Selatan. Terdapat 5 SD Negeri, yaitu SD Negeri 4 Sanur, SD Negeri 3 Sanur, SD Negeri 1 Sanur, SD Negeri 11 Sanur, SD Negeri 8 Sanur. Dengan jumlah populasi siswa kelas V sebanyak 266 Siswa.

Mengingat keterbatasan waktu dan dana dalam penelitian ini maka digunakan sampel penelitian. Penetapan besarnya sampel menggunakan teori R.V. Krecjie and D.W. Morgan dengan tabel untuk menentukan jumlah sampel yang diambil dari populasi secara random dengan tingkat ketelitian $95 \%$ dan taraf signifikansi $5 \%$ untuk proporsi populasi (Agung, 2014). Populasi dalam penelitian ini sebanyak 266 siswa dengan laki-laki sebanyak 141 siswa dan perempuan sebanyak 125 siswa, sehingga banyaknya jumlah sampel sebanyak 155 siswa yang didasarkan pada tabel sebaran teori R.V. Krecjie and D.W. Morgan. Selanjutnya dicari tiap-tiap sampel dari sebaran populasi kelas V SD Gugus I Gusti 
Ngurah Rai Kecamatan Denpasar Selatan dengan teknik sampling yang digunakan yaitu proposional random sampling.

Metode pengumpulan data yang digunakan yaitu menggunakan nontes berupa angket dengan menggunakan model skala likert yang teknik penskorannya menggunakan politomi.

Instrumen efikasi diri disusun melalui konstruk teori dari Albert Bandura (1997) dengan meninjau dari aspek dimensi efikasi yaitu; Level/magnitude, generality, dan strength. Angket yang disusun berdasarkan Morgan-Jinks Student Efficacy Scale yang telah di adaptasi dan di modifikasi sesuai dengan tata bahasa ketercernaan bahasa anak usia sekolah dasar yang terdiri dari item favorable dan item unfavorable.

Instrumen pola asuh orang tua disusun melalui konstruk teori dari Baumrind dengan meninjau dari aspek dimensi pola asuh orang tua yaitu; kontrol dan responsivitas yang diberlakukan oleh orang tua berdasarkan gaya pengasuhan orang tua yang terbagi menjadi 3 tipe yaitu pola asuh authoritarian, permissive, authoritative. Angket yang disusun berdasarkan angket pola asuh orang tua yang disusun oleh Erlina (2016) yang kemudian disesuaikan dengan tata bahasa ketercernaan bahasa anak usia sekolah dasar yang terdiri dari item favorable dan item unfavorable.

Setelah instrumen angket efikasi diri dan pola asuh orang tua dibuat dilanjutkan dengan pengujian validasi teoritik dan validitas empiris. Uji coba dilakukan untuk mendapatkan gambaran secara empirik angket yang telah disusun layak untuk digunakan sebagai instrumen penelitian.

Data penelitian yang sudah terkumpul selanjutnya akan dilakukan analisis data. Kegiatan analisis ini dilakukan setelah data dari seluruh responden dalam sampel dan sumber-sumber lainnya terkumpul. Setelah data terkumpul, data tersebut diolah dan dianalisis. Dalam penelitian ini, analisis data yang digunakan adalah analisis statistik inferensial. Berdasarkan rumusan masalah, uji hipotesis statistik pada penelitian ini dianalisis dengan menggunakan analisis regresi linier sederhana. Untuk bisa menggunakan analisis regresi linier sederhana harus memenuhi dua syarat terlebih dahulu, yaitu normalitas dan linieritas.

Uji normalitas dimaksudkan untuk memperlihatkan bahwa sebaran data sampel berdistribusi normal. Menurut Sugiyono (2017) uji normalitas data dilakukan untuk menentukan apakah data yang diperoleh dapat diuji dengan statistik parametrik atau tidak. Untuk menguji normalitas sebaran data digunakan formula Kolmogorov-Smirnov.

Asumsi kelinearan adalah persamaan linear $Y=b_{0}+b_{1} X$ sesuai dalam menjelaskan pengaruh peubah bebas $\mathrm{X}$ terhadap peubah terikat $\mathrm{Y}$. Uji lack of fit dapat digunakan untuk mengetahui apakah model regresi linear sesuai (fit) untuk menjelaskan pengaruh $X$ terhadap Y.

Hipotesis yang diuji dalam penelitian ini adalah: Tidak terdapat pengaruh pola asuh orang tua terhadap efikasi diri siswa kelas V SD Gugus I Gusti Ngurah Rai Kecamatan Denpasar Selatan Tahun Ajaran 2017/2018. Setelah melalui uji prasyarat analisis dan terpenuhi dilanjutkan dengan uji hipotesis statistik dengan menggunakan analisis regresi linier sederhana.

\section{Hasil dan Pembahasan}

Data pola asuh orang tua siswa kelas V SD Gugus I Gusti Ngurah Rai Denpasar Selatan diperoleh dari data sekunder berupa penyebaran angket pola asuh orang tua. Sampel yang dibagikan angket pola asuh orang tua sebanyak 155 responden dan diberikan sebanyak 30 pernyataan. Berdasarkan data hasil skor pola asuh orang tua diperoleh skor tertinggi adalah 94 dan skor terendah adalah 70. Dengan persentase kencendrungan anak yang diasuh akan digambarkan pada tabel berikut.

Tabel 1. Persentase Kecendrungan Pola Pengasuhan 


\begin{tabular}{cc}
\hline Pola Pengasuhan & Persentase Kecendrungan \\
\hline Authoritatif & $94 \%$ \\
Authoritarian & $5 \%$ \\
Permissive & $0,6 \%$ \\
\hline
\end{tabular}

Berdasarkan hasil analisis uji normalitas sebaran data pada taraf signifikansi $5 \%$ dan $\mathrm{dk}(1-\alpha ; n)$ diperoleh $\mathrm{KS}_{\text {tabel }}=0,10$. Hasil analisis uji normalitas sebaran data pola asuh orang di dapatkan hasil $\mathrm{KS}_{\text {hitung }} 0,08$. Karena $\mathrm{KS}_{\text {hitung }} 0,08<\mathrm{KS}_{\text {tabel }} 0,10$, maka $\mathrm{H}_{0}$ diterima yang berarti data berdistribusi normal.

Data efikasi diri siswa kelas V SD Gugus I Gusti Ngurah Rai Denpasar Selatan diperoleh dari penyebaran angket efikasi diri. Sampel yang dibagikan angket pola asuh orang tua sebanyak 155 responden dan diberikan sebanyak 30 pernyataan. Berdasarkan data hasil skor efikasi diri diperoleh skor tertinggi adalah 117 dan skor terendah adalah 69 . Dengan persentase anak yang memiliki efikasi diri akan digambarkan pada tabel berikut.

Tabel 2. Persentase Efikasi Diri Siswa Kelas V SD Gugus I Gusti Ngurah Rai Kecamatan Denpasar Selatan

\begin{tabular}{cc}
\hline Dimensi Efikasi & Persentase Kecendrungan \\
\hline Level/magnitude & $27 \%$ \\
Generality & $22 \%$ \\
Strength & $51 \%$ \\
\hline
\end{tabular}

Berdasarkan hasil analisis uji normalitas sebaran data efikasi diri di dapatkan hasil $\mathrm{KS}_{\text {hitung }} 0,05$. Karena $\mathrm{KS}_{\text {hitung }} 0,05<\mathrm{KS}_{\text {tabel }} 0,10$, maka $\mathrm{H}_{0}$ diterima yang berarti data berdistribusi normal.

Berdasarkan uji linieritas pada taraf signifikansi $5 \%$ dan dk ( $\alpha, k-2, n-k)$ diperoleh $F_{\text {tabel tc }}=1,70$. Hasil analisis uji linieritas di dapatkan hasil $F_{\text {hitung tc }} 1,58$. Karena $F_{\text {hitung tc }} 1,58<$ $F_{\text {tabel tc }} 1,70$, maka $\mathrm{H}_{0}$ diterima yang berarti data linier.

Berdasarkan hasil uji normalitas dan uji linieritas dapat diketahui bahwa data yang diperoleh dari variabel pola asuh orang tua dan efikasi diri berdistribusi normal dan memiliki linieritas. Data yang diperoleh telah memenuhi uji prasyarat, maka uji hipotesis dilakukan dengan menggunakan analisis regresi linier sederhana.

Berdasarkan perhitungan koefisien $b_{1}$ dan $b_{0}$ di dapatkan model regresi yakni Efikasi Diri $=65,89+0,34$ Pola Asuh Orang Tua. Untuk menguji signifikansi model regresi digunakan perhitungan dengan tabel anava sebagai berikut.

Tabel 3. Hasil Perhitungan dengan Menggunakan Tabel Anava

\begin{tabular}{|c|c|c|c|c|c|}
\hline \multicolumn{6}{|c|}{ Tabel Anava } \\
\hline Sumber & $\mathrm{db}$ & $\mathrm{JK}$ & $\mathrm{KT}$ & Fhitung & Ftabel \\
\hline Regresi & 1 & 365,9 & 365,9 & 5,34 & 3,90 \\
\hline Sisa & 153 & 10483,78 & 68,5 & & \\
\hline Lack of Fit (Tc) & 17 & 2592,6 & 152,5 & 1,58 & 1,70 \\
\hline Galat & 136 & 7891,22 & 96,4 & & \\
\hline Total & 154 & 10850 & & & \\
\hline & $\mathrm{R}^{2}$ & 0,035 & & & \\
\hline & $r$ & 0,19 & & & \\
\hline
\end{tabular}

Berdasarkan hasil analisis data diketahui antara pola asuh orang tua $(\mathrm{X})$ dengan efikasi diri (Y) siswa kelas V SD Gugus I Gusti Ngurah Rai Kecamatan Denpasar Selatan Tahun Ajaran 2017/2018 dengan nilai $F_{\text {hitung regresi }}=5,34$, dan $F_{\text {tabel regresi }}=3,90(n=155)$ pada taraf signifikansi $5 \%$ dengan db (regresi) 1 menerima $\mathrm{H}_{a}$ yang menyatakan terdapat pengaruh pola asuh orang tua terhadap efikasi diri siswa kelas V SD Gugus I Gusti Ngurah 
Rai Kecamatan Denpasar Selatan Tahun Ajaran 2017/2018 dengan koefisien determinasi $R^{2}=0,035$. Jika dipersentase, $R^{2}(0,035) \times 100 \%$ di peroleh hasil sebesar $3,5 \%$ artinya pola asuh memberikan kontribusi efikasi diri sebesar 3,5\%.

Berdasarkan hasil pembahasan di atas pola asuh orang tua memberikan kontibusi efikasi diri sebesar 3,5\%. Pemberian perlakuan dan pengasuhan yang tepat akan meningkatkan efikasi anak tersebut. Lewat lingkungan keluarga yang baik awal pembentukan efikasi anak akan dapat ditingkatkan. Hal tersebut juga berkaitan erat dengan sumber efikasi yang menyebutkan bahwa anak akan cenderung mengikuti model sosial serta dukungan sosial dari orang terdekat dan paling lekat dengan kehidupan anak yakni orang tua. Orang tua akan sebagai figur pertama yang akan diamati oleh anak. Apabila sosok figur yang diamati memiliki keberhasilan dan mendukung anak, maka akan cenderung memiliki efikasi yang tinggi, sebaliknya efikasi diri akan menurun jika figur yang diamati oleh anak memiliki kegagalan dan kurang mendukung anak. Jelas maka efikasi diri dapat ditingkatkan dan diturunkan oleh dukungan dan peran orang tua. Lebih lanjut ada beberapa faktor yang mempengaruhi efikasi anak itu sendiri yakni dari budaya yang dianut oleh orang terdekat anak yang dapat memberikan penilaian efikasi anak apakah anak tersebut tinggi atau rendah. Kemudian berdasarkan gender yang mempengaruhi efikasi diri. Anak perempuan cenderung memiliki efikasi diri yang tinggi dibandingkan anak laki-laki karena anak perempuan dapat mengelola tugas-tugas yang diberikan dibandingkan anak laki-laki. Selanjutnya bedasarkan sifat tugas yang dihadapi, kecendrungan insentif eksternal, Status atau peran anak tersebut dalam lingkungannya, dan informasi tentang kemampuan dirinya baik positif maupun negatif sama-sama memiliki kecendrungan untuk dapat meningkatkan atau dapat menurunkan efikasi diri anak. Efikasi diri memiliki kaitan yang erat dengan orang tua terutama terletak bagaimana anak tersebut di berikan perlakuan maupun pengasuhan. Pemberian perlakuan dan pengasuhan yang tepat akan meningkatkan efikasi anak tersebut.

Hal tersebut didukung oleh pendapat dari Bandura (1997) yang menyatakan bahwa ada beberapa faktor lain mempengaruhi efikasi diri pada individu selain pola pengasuhan orang tua antara lain; 1) budaya; budaya dapat mempengaruhi efikasi diri melalui nilai, kepercayaan, dan proses pengaturan diri yang berfungsi sebagai salah satu sumber penilaian efikasi diri dan sebagai konsekuensi dari keyakinan akan efikasi diri siswa tersebut. 2) gender; perbedaan gender juga dapat mempengaruhi efikasi diri siswa hal ini berkaitan dengan bagaimana individu tersebut mengelola perannya. Anak perempuan terbiasa untuk membantu tugas dari ibunya dirumah hal ini berbanding terbalik dengan anak laki-laki yang cenderung tidak terbiasa untuk membantu ibunya. Maka daripada itu anak perempuan cenderung memiliki efikasi diri yang tinggi dibandingkan dengan anak laki-laki. 3) sifat dari tugas yang dihadapi; apabila anak ditugaskan mengerjakan pekerjaan yang menurut mereka rumit anak akan cenderung menilai bahwa ia tidak mampu menyelesaikan pekerjaan tersebut. Berlaku juga sebaliknya apabila anak tersebut ditugaskan mengerjakan pekerjaan yang mudah dan sederhana bagi mereka. Maka anak tersebut akan tinggi menilai kemampuannya sehingga akan menyebabkan efikasi diri anak tersebut meningkat. 4) insentif eksternal; pemberian hadiah, dukungan serta motivasi yang tepat maka akan dapat meningkatkan efikasi siswa tersebut. 5) status atau peran anak dalam lingkungan baik lingkungan keluarga, sekolah, dan masyarakat. Apabila anak berada dalam situasi ia diperhatikan dan disayang anak tersebut akan merasa bahwa dirinya berarti sehingga akan meningkatkan efikasi diri anak tersebut serta yang terakhir yaitu, 6) informasi tentang kemampuan dirinya, apabila anak diberikan informasi yang positif mengenai kemampuan dirinya maka akan meningkatkan efikasi diri anak tersebut. Berlaku juga sebaliknya apabila anak mendapatkan informasi yang negatif mengenai kemampuan dirinya tanpa adaya dukungan dari orang terdekatnya maka efikasi diri anak akan menurun dan cenderung rendah menilai dirinya. Selain itu Bandura menyebutkan bahwa selain faktor-faktor yang mempengaruhi diatas adapula sumber-sumber yang dapat menurunkan dan meningkatkan efikasi diri siswa. Seperti pengalaman anak tersebut di masa lalu apabila anak tersebut memiliki keberhasilan di masa lalu anak akan mulai menekuni dan menjadikan hal tersebut bagian dari kegemaran anak tersebut. Berbanding halnya apabila anak tersebut mengalami 
kegagalan maka anak akan cenderung menghindari hal tersebut. Selanjutnya yakni pengalaman vikarius yang diperoleh dari model sosial, persuasi sosial dan keadaan emosi anak tersebut. Jelaslah bahwa efikasi diri anak dapat meningkat dan menurun bergantung kepada bagaimana anak tersebut menilai kemampuan dirinya. Maka dari pada itu perlu adanya dukungan serta motivasi dari lingkungan sekitar siswa untuk dapat memberikan semangat untuk meyakinkan siswa tersebut dapat melewati berbagai permasalahan serta tantangan yang dihadapi.

\section{Simpulan dan Saran}

Berdasarkan hasil analisis dan pembahasan dapat disimpulkan bahwa terdapat pengaruh pola asuh orang tua terhadap efikasi diri siswa kelas V SD Gugus I Gusti Ngurah Rai Kecamatan Denpasar Selatan Tahun Ajaran 2017/2018. Hal ini di buktikan dengan hasil Fhitung regresi $=5,34$ dan Ftabel regresi $=3,90$ yang berarti Fhitung regresi $=5,34>$ Ftabel regresi $=3,90$, sehingga $\mathrm{Ha}$ yang menyatakan terdapat pengaruh yang signifikan pola asuh orang tua terhadap efikasi diri siswa kelas V SD Gugus I Gusti Ngurah Rai Kecamatan Denpasar Selatan tahun ajaran 2017/2018 diterima. Nilai Fhitung regresi $=5,34$ tersebut juga menunjukkan bahwa terjadi pengaruh positif pola asuh orang tua terhadap efikasi diri siswa. Koefisien determinasi menunjukan sebesar 3,5\% variasi efikasi diri ditentukan oleh pola asuh orang tua. Berdasarkan hasil analisis tersebut dapat diinterpretasikan bahwa, pola asuh berpengaruh terhadap efikasi diri. Hal ini dibuktikan dari pola asuh orang tua memiliki kontribusi 3,5\% terhadap efikasi siswa. Artinya ada faktor yang mendominasi selain faktor pola pengasuhan orang tua. Berdasarkan dengan teori yang di kemukakan oleh Bandura bahwa ada faktor lain yang mempengaruhi seseorang. Namun yang jelas bahwa efikasi diri seseorang bergantung kepada bagaimana orang tersebut menilai kemampuannya.

Adapun saran yang dapat disampaikan berdasarkan hasil penelitian yang telah dilakukan yaitu: untuk orang tua agar dapat memberikan contoh yang baik, dukungan dan kasih sayang agar anak dapat mengembangkan efikasi diri yang positif. Karena anak belajar dari pengamatan orang tedekatnya, sehingga anak perlu untuk mendapatkan lingkungan yang baik untuk dipelajari dan ditirunya. Lewat pengasuhan yang baik dan tepat maka anak akan dapat mengembangkan efikasi diri secara maksimal. Selain itu perlu peran dari guru agar dapat memberikan dukungan, motivasi dan perhatian kepada siswa. Karena peran serta guru di sekolah juga sangat menentukan pembentukan efikasi diri pada siswa. Guru dapat menciptakan suasana pembelajaran yang menyenangkan sehingga membuat siswa menjadi nyaman dan termotivasi untuk beradaptasi dengan lingkungan sekitarnya.

\section{Daftar Pustaka}

Agung, A.A.G. 2014. Buku Ajar Metodologi Penelitian Pendidikan. Yogyakarta: Aditya Media Publishing.

Alwisol. 2014. Psikologi Kepribadian Edisi Revisi. Malang: UMM Press.

Anwar, A.I. 2009. "Hubungan antara Self Efficacy dengan Kecemasan Berbicara di Depan Umum pada Mahasiswa Fakultas Psikologi Universitas Sumatra Utara".

Baumrind, Diana. 1966. Effects of Authoritative Parental Control on Child Behavior. Child Development. 37 (4), 887 - 907.

Baumrind, Diana. 1991. The Influence of Parenting Style on Adolescent Competence and Substance Use. Journal of Early Adolescense. 11 (1), 56 -59.

Bandura, A. 1977. Self-efficacy: Toward a Unifying Theory of Behavioral Change. Psychological Review. Vol.84, No.2 (hlm.191-215).

Bandura, A. 1997. Self-Efficacy The Exercise of Control. New York: W.H. Freeman and Company.

Erlina, Winda. 2016. "Pola Asuh Orang Tua sebagai Prediktor Kecerdasan Emosional pada Remaja"

Jinks, J. \& Morgan, V. (1999). "Children's perceived academic self-efficacy: An inventory scale”. Vol.72, No. 4 (hlm 224-230). 
Mulyadi, Seto, dkk. 2016. Psikologi Pendidikan akan Pendekatan Teori-Teori Baru dalam Psikologi. Jakarta: Rajawali Pers.

Santrock, John W. 2007. Perkembangan Anak, edisi kesebelas, jilid I. Terjemahan Mila Rachmawati dan Anna Kuswanti. Jakarta: Erlangga.

Santrock, John W. 2007. Perkembangan Anak, edisi ketujuh, jilid II. Terjemahan Mila Rachmawati dan Anna Kuswanti. Jakarta: Erlangga.

Slavin, Robert E. 2011. Psikologi Pendidikan Teori dan Praktik. Jakarta: Indeks.

Sugiyono. 2017. Statistika untuk Penelitian. Bandung: Alfabeta.

Taylor, Shelley E, dkk. 2009. Psikologi Sosial. Jakarta: Kencana.

Yusuf, Syamsu. 2017. Psikologi Perkembangan Anak \& Remaja. Bandung: Remaja Rosdakarya. 